\title{
Ascidians Outbreak: A Threat For Coral Reefs in Panjang Island, Jepara
}

\author{
Dwi Haryanti*, Diah Permata Wijayanti, Bambang Yulianto, \\ Mada Triandala Sibero, Lutfillah Arief Ghinaa Shabrina
}

\author{
Marine Science Department, Faculty of Fisheries and Marine Science, Universitas Diponegoro \\ Jl. Prof. H. Soedarto, Tembalang, Semarang 50275, Indonesia \\ E-mail: dwiharyanti@live.undip.ac.id
}

\begin{abstract}
Eutrophication and sedimentation have become a major threat to coral reefs in nearby areas with anthropogenic activities. These threats are often accompanied by shifting ecosystems from coralrich to fast-growing algae-dominated water, and high prevalence of coral disease. In Panjang Island, Jepara, we observed the outbreak of photosynthetic ascidians along with a high sedimentation at the eastern part of the island. The ascidians were seen overgrowing most substrates including corals, macroalgae, dead-coral-algae, and rubbles in April to May 2019. In July and August 2019, observation and data collection using quadrant transect were conducted to monitor the outbreak. The result showed that ascidians were still present in the area, despite becoming pale and smaller. This report shows that the outbreak of these photosynthetic ascidians was not persistent, however, the effect on coral reef health should not be overlooked.
\end{abstract}

Keywords: Ascidians, outbreak, coral reefs, Indonesia

\section{INTRODUCTION}

Space competition in coral reefs has become a major problem following the increasing nutrient run-off from anthropological activities in the coastal area, as well as environmental change in a local, regional and global scale. Other than the competition with algae (Bakker et al 2017), space competition with other marine benthic animals such as ascidians was recently reported. In Carribean, the ascidian Trididemnum solidum was reported to overgrow scleractinian corals (RodríguezMartínez et al., 2012). Ascidian outbreak was also reported from the Pacific in American Sãmoa, where Diplosoma simile threaten the existence of scleractinian corals in the area (Vargas-Ángel et al., 2009). We observed the distinct presence of photosymbiotic 'green gum drop' ascidians Diplosoma sp. (Su et al 2013 and Hirose et al 2014) overgrowing corals in the water of Panjang island, located $2 \mathrm{Km}$ off Jepara coast, Central Java, Indonesia in April 2019. Diplosoma ascidians are known to harbour Prochloron, a photosymbiontic cyanobacteria (Hirose and Nozawa, 2010), therefore often found living in shallow water.
Numerous research have been conducted in Panjang island, Jepara, from the bioecology (Suryono et al., 2021), physical oceanography and geomorphology (Sugianto et al., 2019) and biodiversity (Sabdono et al., 2021) and coral reef restoration (Munasik et al., 2021). However, a phenomena where ascidian is rapidly growing in the island has never been reported before.

We do not know the nature of these ascidians' occurrence, whether it is an outbreak or an ecosystem shift, as in algae. Understanding the photosymbiotic 'green gum drop' ascidians relationship with environment dynamics, as well as monitoring, is important to identify local disturbance that could potentially decrease coral coverage in a short time. Therefore, we aim to record the occurrence of photosynthetic ascidian in Panjang island over a time period of five months and discuss the consequences we need to face as the environment is changing.

\section{MATERIAL AND METHOD}

Preliminary observations took place at Panjang Island, located $2 \mathrm{~km}$ off Jepara coast 
Central Java, Indonesia in April and May 2019. The observation was conducted in the southwestern and the eastern part of the island (Figure 1). The timed swim was around one hour for each site, covering an area of approximately $500 \mathrm{~m}^{2}$. Coral reefs at the depth of $0.5-3 \mathrm{~m}$ were observed and various substrates competing with or overgrown by ascidians were photographed using an underwater camera (Nikon W300).

\section{Outbreak monitoring}

Monitoring was conducted in July and August 2019 following the preliminary observations following a modification of IUCN protocol for the Resilience Assessment of Coral Reefs (Obura and Grimsditch, 2009). In July, a permanent transect mark was installed at the eastern site. A floating buoy was added to mark the beginning and the end of the $50 \mathrm{~m}$ transect (Figure 1, A and B), parallel to the shoreline. Monitoring was not conducted at the southwestern part of the island because only one type of ascidian was found on rubble, and the number was very low.

Quadrant transect $(0.5 \times 0.5 \mathrm{~m})$ with a partition of $10 \times 10 \mathrm{~cm}$ (25 squares in each quadrant transect) was photographed along the $50 \mathrm{~m}$ line transect, with the interval of $10 \mathrm{~m}$ $(0,10,20$, and so on). Five random squares from each quadrant photos were then analyzed. The substrates were categorized into hard corals $(\mathrm{HC})$, sponge, sediment, ascidian (Asc), crustose coralline algae (CCA), macroalgae (MA), and seagrass. The percentage of each substrate was estimated and the average value was calculated from a total of 6 transects (30 squares) from each site.

\section{RESULT AND DISCUSSION}

During preliminary observation, two types of photosynthetic ascidian (Diplosoma gumavirens Hirose et al., 2009 and Diplosoma sp.) were found in Panjang island. Only Diplosoma gumavirens was found in the southwest in a small number, mostly growing on rubble, while Diplosoma gumavirens and Diplosoma sp. were found abundant in the eastern part of the island (Figure 2). We found the two types of Diplosoma covering various substrates such as hard corals (Figure 2 and 3 ), macroalgae, and even seagrass. On massive Porites, a change in coral pigmentation was observed along with the tissues in contact with the ascidian (white arrow, Figure 2A, Figure 3B, $3 \mathrm{E}$, and $3 \mathrm{~F}$ ).

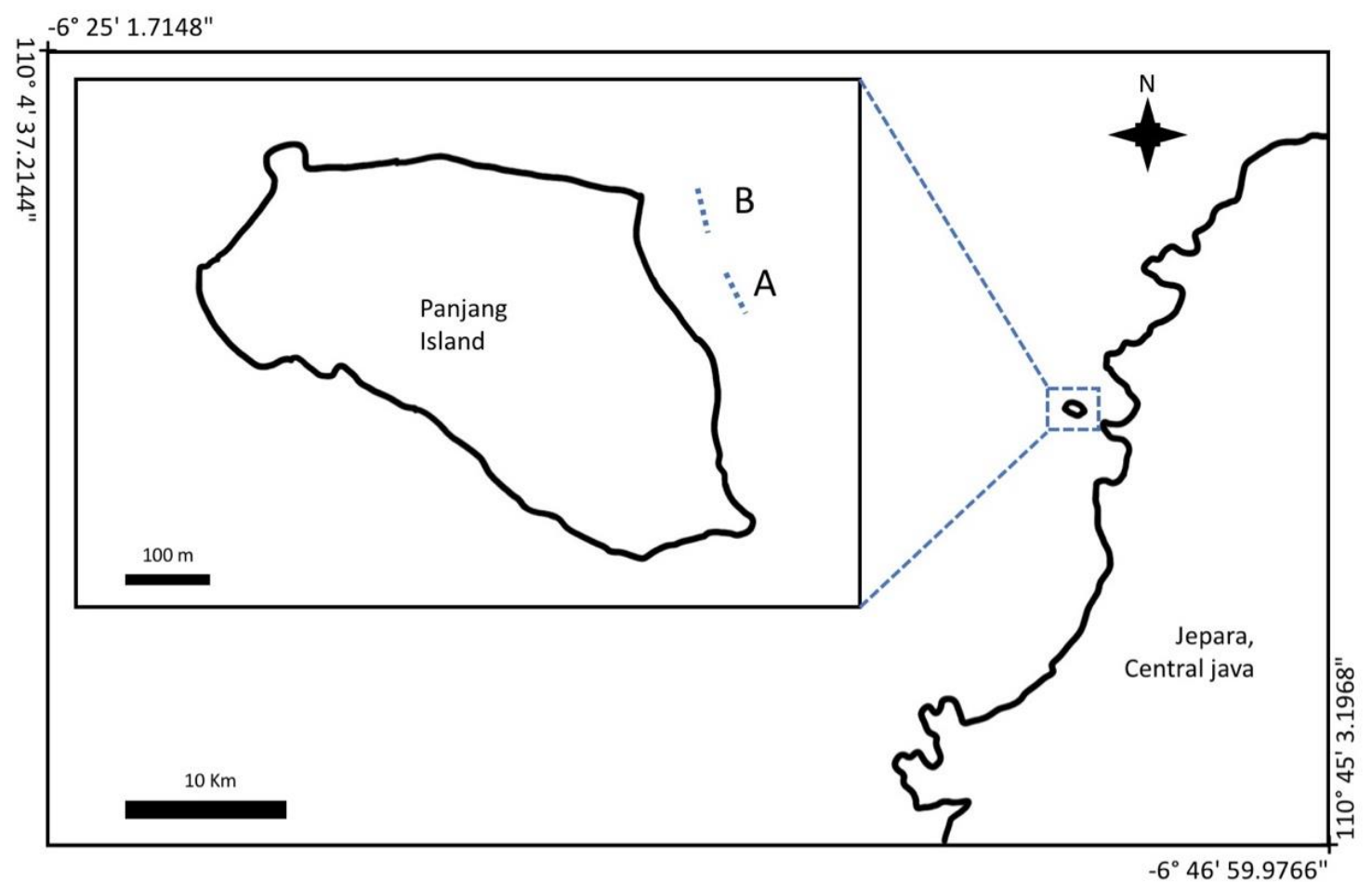

Figure 1. Sampling location at Panjang Island, Jepara, Central java. Transect A and B are $50 \mathrm{~m}$ each. 


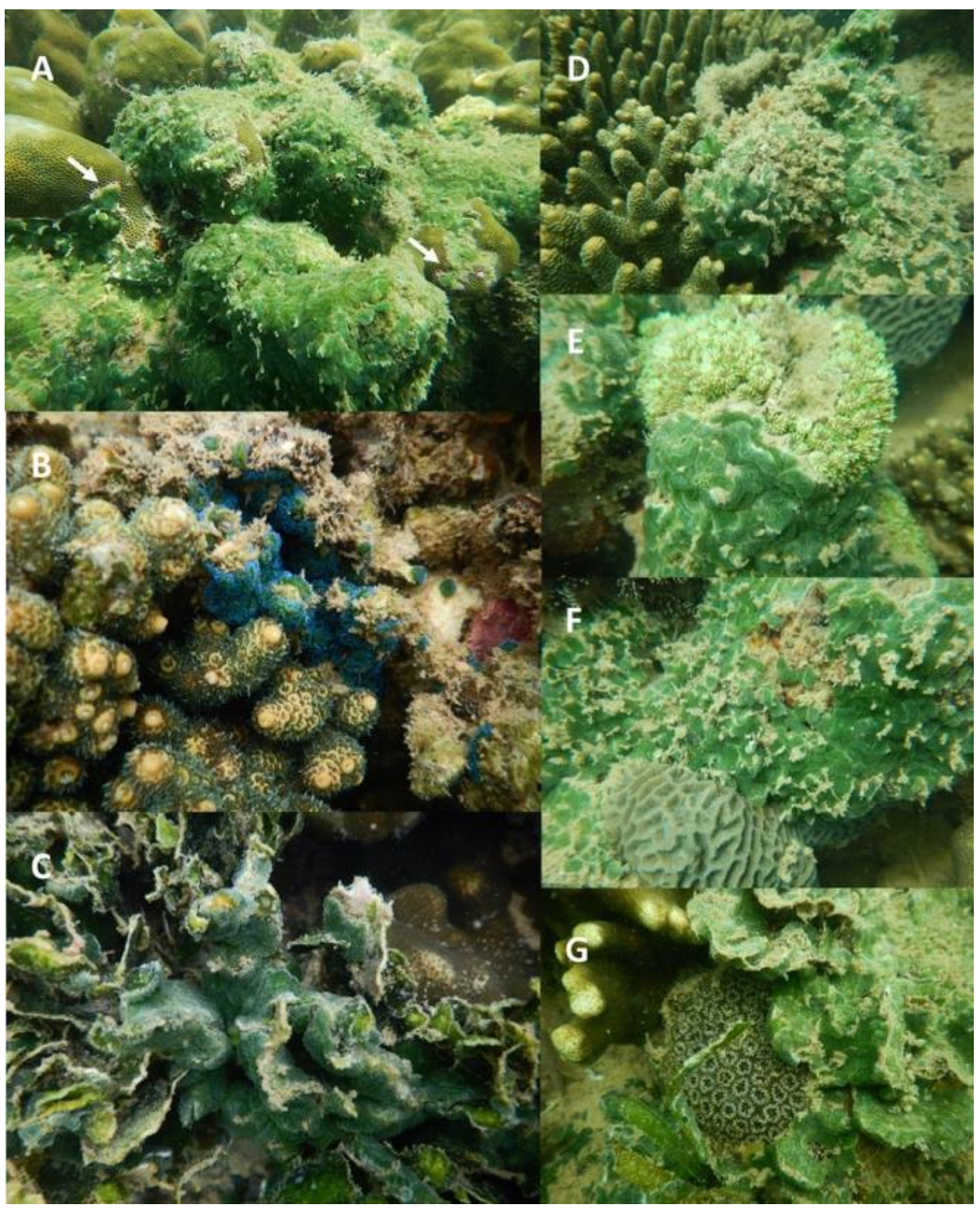

Figure 2. Ascidians overgrowing corals and another substrate in Panjang Island, Jepara, in April and May: A, Porites coral overgrown by Diplosoma sp. showing a change in pigment coloration; B, Diplosoma gumavirens overgrowing Acropora; C, Diplosoma sp. overgrowing Halimeda macroalgae; D, Diplosoma sp. overgrowing Acropora along with high sedimentation; E, Diplosoma sp. overgrowing Galaxea coral; F, Diplosoma sp. overgrowing Goniastrea coral; G, Diplosoma sp. overgrowing massive corals and seagrass.

D'Angelo et al. (2012) stated that corals show a change in tissue pigmentation as an innate immune response to disturbance such as when branching corals are broken and then recovers, or when Porites corals are wounded by parrotfish or burrowing animals. In this study, the Porites corals seem to change their coloration at the contact borders with ascidian as a defence mechanism.
Diplosoma sp. was also found covering macroalgae such as Halimeda (Figure 2C) and Sargassum (Figure 3A). Macroalgae have become abundant in Panjang island following the increase of nutrient input from nearby land. Similar to macroalgae, photosynthetic ascidian in Panjang island is getting a chance to grow rapidly in the shallow area with rich nutrients and sunlight. However, the 
consequences of competition between macroalgae and ascidian for the ecosystem still need to be explored.

Following the preliminary observation, monitoring in July and August shows a changing shape and colors of Diplosoma sp. In the previous months, the Diplosoma shows distinct green color, round or elongated colonies with a diameter of $0,5-1 \mathrm{~cm}$. In July and August, as the sedimentation in Panjang island increased, the Diplosoma sp. are becoming smaller and pale (Figure 3E \& 3F). This might be caused by a decreasing light intensity available for photosynthesis. Similar phenomena was observed in Singapore (Su et al., 2013), where the water has become turbid due to coastal development, resulting in a decreasing suitable habitat for photosynthetic ascidians. However, Diplosoma gumavirens did not show any changes in either coloration or size. The two types of ascidians might have different tolerance to changing light environments. Photosynthetic ascidians coverage decreased from $4.17 \pm 1.78 \%$ in July to $1.70 \pm 1.17 \%$ in August at site A and from $3.17 \pm 0.76 \%$ in July to $2.00 \pm 0.67 \%$ in August at site B (Table 4). Diplosoma sp. which was found covering various substrate in the area seems to be growing faster with abundant nutrients and clear water then become unhealthy once the light intensity decrease during turbid months (Figure 4).

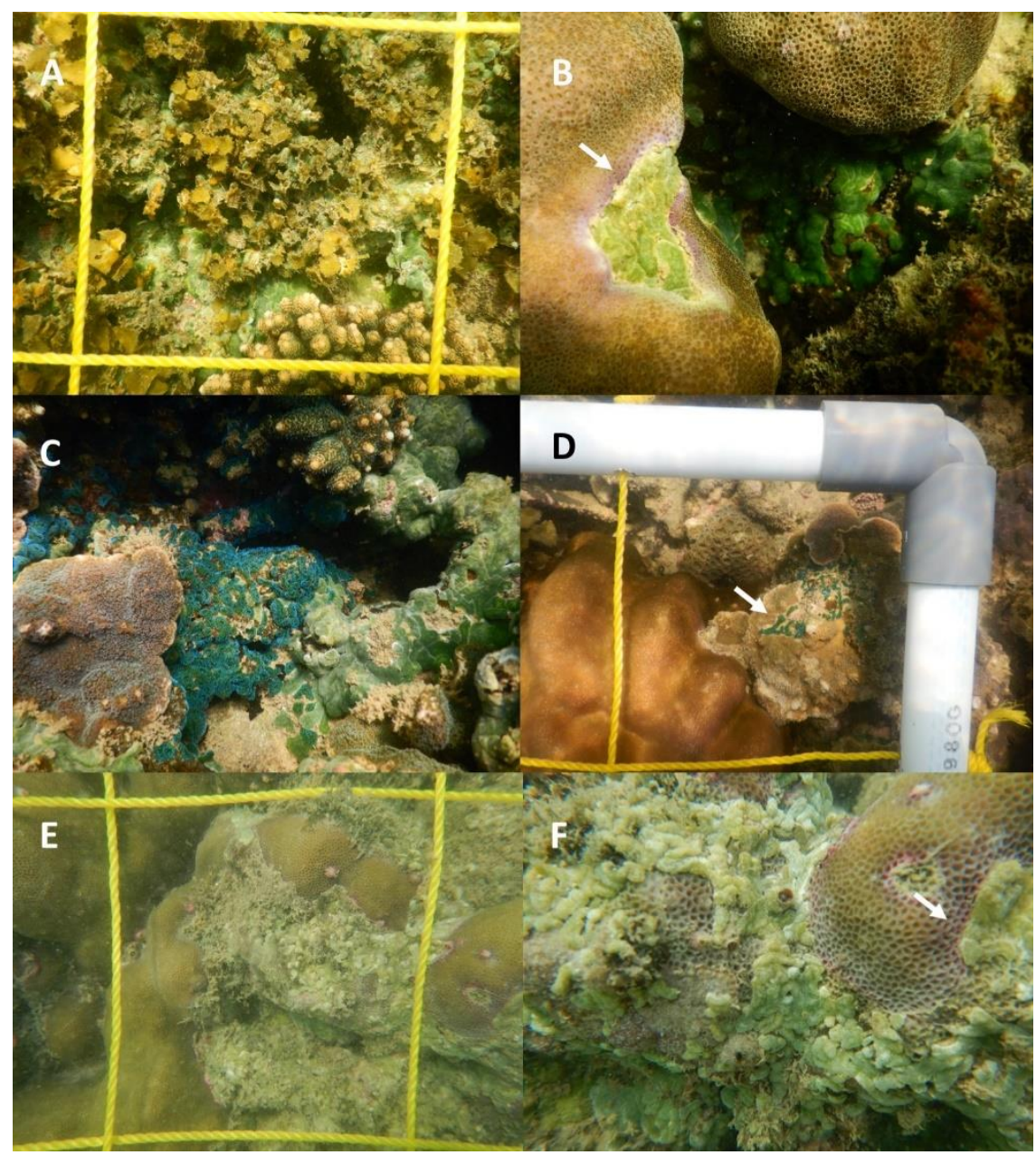

Figure 3. Monitoring results in July (A-D) and August (E-F) show that Diplosoma are still found overgrowing corals and other substrates. A, Diplosoma sp. overgrowing Sargassum macroalgae; B, Diplosoma sp. overgrowing Porites coral with a change in pigment coloration; C, Two types of Diplosoma overgrowing corals; D. Diplosoma gumavirens overgrowing encrusting Montipora showed in quadrant transect; $\mathbf{E}$ \& $\mathbf{F}$, remaining massive Porites after invasion by Diplosoma sp. showing a change in pigment coloration. 
Tabel 1. Percent coverage of substrate (mean \pm SE). HC: hard coral, Asc: photosynthetic ascidian, CCA: crustose coralline algae, MA: macroalgae

\begin{tabular}{lcccc}
\hline \multicolumn{1}{c}{ Substrate } & July-A & August-A & July-B & August-B \\
\hline Sponge & $11.33 \pm 5.14$ & $3.00 \pm 2.10$ & 0 & 0 \\
HC & $5.00 \pm 1.75$ & $13.97 \pm 4.89$ & $29.63 \pm 6.17$ & $21.43 \pm 5.75$ \\
Sediment & $31.17 \pm 4.98$ & $43.83 \pm 6.64$ & $60.63 \pm 5.99$ & $56.97 \pm 5.76$ \\
AsC & $4.17 \pm 1.78$ & $1.70 \pm 1.17$ & $3.17 \pm 0.76$ & $2.00 \pm 0.67$ \\
CCA & $1.00 \pm 1.00$ & $0.50 \pm 0.37$ & $1.07 \pm 0.47$ & $3.77 \pm 0.77$ \\
MA & $21.83 \pm 5.94$ & $13.83 \pm 4.18$ & $5.50 \pm 1.94$ & $15.83 \pm 3.88$ \\
Seagrass & $25.50 \pm 7.41$ & $23.17 \pm 7.32$ & 0 & 0 \\
\hline
\end{tabular}

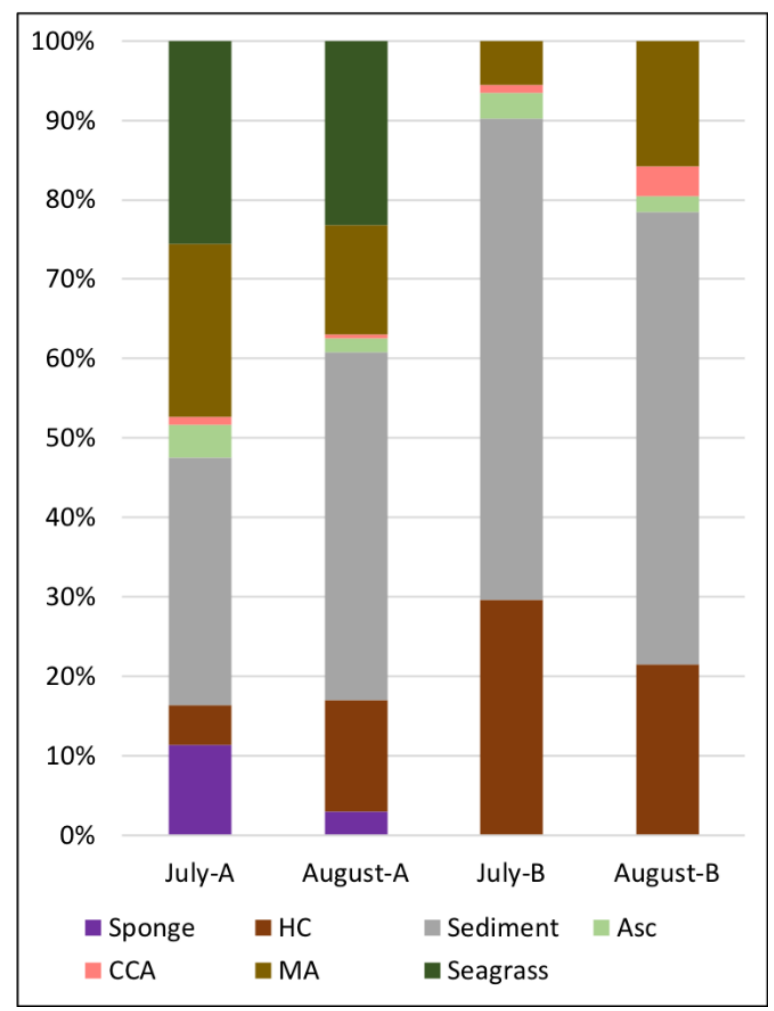

Figure 4. Percent cover of various substrates found in the shallow reef of Panjang island. The substrate in Panjang Island, Jepara, with domination of sedimented surface, macroalgae, and corals.

On a side note, the high level of sedimentation on this island should not be overlooked. The presence of photosynthetic ascidians was often accompanied by particles similar to sediment, however the properties of these sediments should be investigated further, since higher nutrients also increase the suspended bacteria (Bak et al., 1996) and possibly another microbiome in the water and sediments. The presence of sediments along with low coverage of CCA (Table 1 and Figure 4) give less chance for corals larvae to settle, resulting in challenges for the coral population to recover from disturbances. This study was conducted in a time frame of 5 months, starting in April 2019, when Panjang island and Java sea in general is in a shifting period from western monsoon to eastern monsoon and the water is generally calm (Supriharyono, 1998). Meanwhile, July and August is the eastern monsoon and the eastern part of the island generally receives more wind (windward) and the water is often mixed and become more turbid. The outbreak 
that occurred in 2019 might be seasonal, triggered by a rich nutrient availability after the western monsoon and clear water during the calm period in March-April.

Since fast-growing ascidian seems to be a strong competitor in shallow reef areas and could kill corals in a relatively short time (Figure $3 \mathrm{E}$ and $3 \mathrm{~F}$ ), the effects of such occurrence need further investigation. A broader monitoring site and longer time period of the survey will help reveal whether the outbreak occurs annually and whether corals in Panjang island could recover after the outbreak.

\section{CONCLUSION}

Ascidian outbreaks potentially reduce coral cover in a short time. From these observations, important questions remain for further studies, including how rapid is the ascidian growth in Panjang island; what environmental factors are favorable for ascidian outbreak; what substances are in charge of defense in photosynthetic ascidians; and, are the sediment covering most of the area bringing other properties such as heavy metal, or are they rich in pathogenic microbiomes.

\section{ACKNOWLEDGEMENT}

We would like to thank the Faculty of Fisheries and Marine Science for the funding and support for this study, and the local tourism manager in Panjang Island, Agus Susanto, for the field assistance. This work was carried out under the Faculty of Fisheries and Marine Science Competitive Grant, Diponegoro University, 2019 (grant number 79/UN7.5.10/HK/2019).

\section{REFERENCES}

Bak, R.P.M., Lambrechts, D.Y.M., Joenje, M., Nieuwland, G. \& Van Veghel, MLJ.1996. Long-term changes on coral reefs in booming populations of a competitive colonial ascidian. Marine Ecology Progress Series 133:303-306.

de Bakker, D.M., van Duyl, F.C., Bak, R.P.M., Nugues, M.M., Nieuwland, G. \& Meesters, E.H. 2017. 40 years of benthic community change on the Caribbean reefs of Curaçao and Bonaire: the rise of slimy cyanobacterial mats. Coral Reefs, 36:355367.

D'Angelo, C., Smith, E.G., Oswald, F., Burt, J., Tchernov, D. \& Wiedenmann J. 2012. Locally accelerated growth is part of the innate immune response and repair mechanisms in reef-building corals as detected by green fluorescent protein (GFP)-like pigments. Coral Reefs., 31:10451056.

Hirose, E., Oka, A.T. \& Hirose, M. 2009. Two New Species of Photosymbiotic Ascidians of the Genus Diplosoma from the Ryukyu Archipelago, with Partial Sequences of the COI Gene. Zoological Science, 26(5):362-368.

Hirose E. \& Nozawa Y. 2011. Photosymbiotic ascidians from Kenting and Lyudao in Taiwan. Zoological Studies, 49:681-687.

Hirose, E., Iskandar, B.H. \& Wardiatno, Y. 2014. Photosymbiotic ascidians from Pari Island (Thousand Islands, Indonesia). ZooKeys, 422: p.1.

Munasik, M., Sabdono, A., Hutapea, E.D., Sugiyanto, S. \& Sugianto, D.N. 2021. Coral Recruitment on Artificial Patch Reefs Deployed in The Marginal Reefs: Effect of Multilevel Substrate on Density of Coral Recruit. Jurnal Segara, 17(1):33-42. doi: 10.15578/segara.v17i1. 10064.

Obura, D.O. \& Grimsdicth, G. 2009 Resilience Assessment of coral reefs - Assessment protocol for coral reefs, focusing on coral bleaching and thermal stress. IUCN working group on Climate Change and Coral Reefs. IUCN, Gland, Switzerland. 70 p.

Rodríguez-Martínez, R.E., Jordán-Garza, A.G., Baker, D.M. \& Jordán-Dahlgreen, E. 2012. Competitive interactions between corals and Trididemnum solidum on Mexican Carribean reefs. Coral Reefs, 31:571-577. doi : 10.1007/s00338-011-0871-y

Sabdono, A., Radjasa, O.K., Trianto, A., Sibero, M.T., Martynov, A. \& Kristiana, R. 2021. An ecological assessment of nudibranch diversity among habitats receiving different degrees of sedimentation in jepara coastal waters, Indonesia. Internasional Journal of Conservation Science, 12(1):291-302 
Supriharyono, . 1998. Skeletal Banding Pattern and Growth Rates of the Massive Coral Porites Lutea Edwards \& Haime on the North Coast of Central Java, Indonesia. Journal of Coastal Zone Management, 2(1):307-317.

Suryono, Ambariyanto, A., Munasik, Wijayanti, D.P., Ario, R., Pratikto, I., Taufiq-Spj, N., Canavaro, S.V., Anggita, T., Sumarto, B.K.A. \& Cullen, J. 2021. Bioecology of coral reef in Panjang Island of Central Java Indonesia. Ilmu Kelautan : Indonesian Journal of Marine Sciences, 26(2):125-134. doi: 10.14710/ik.jjms.26.2.125-134

Su, S.W., Hirose, E., Chen, S.L.S. \& Mok, M.H.K. 2013. Photosymbiotic ascidians in Singapore: turbid waters may reduce living space ZooKeys, 305:55-65. doi: 10.3897/zookeys.305.4893

Vargas-Ángel B., Asher, J., Godwin, L.S. \& Brainard, R.E. 2009. Invasive didemnid tunicate spreading across coral reefs at remote Swains Island, American Sāmoa. Coral Reefs, 28: p53. doi: 10.1007/s00338008-0428-x 